\title{
Self-Reported Spiritual Care among Moslem ICU Nurses in the Rural Area of Indonesia
}

\author{
Benny Arief Sulistyanto ${ }^{1}$, Intana Vita Silma Khonita ${ }^{2}$, Irnawati ${ }^{3}$, Nenden Lesmana Wati ${ }^{4}$ \\ ${ }^{1,2,3}$ Universitas Muhammadiyah Pekajangan Pekalongan \\ ${ }^{4}$ Faletehan University
}

\begin{tabular}{l} 
ARTICLE INFO \\
\hline Article history: \\
DOI: \\
10.30595/pshms.v2i.245 \\
Submitted: \\
December 6, 2021 \\
Accepted: \\
January 21, 2022 \\
Published: \\
January 26, 2022 \\
Keywords: \\
Spiritual \\
therapies; \\
spirituality
\end{tabular}

\begin{abstract}
Spiritual care is very important particularly for patients who are experiencing critical conditions. Although the priority of critical care is to maintain the function of the organ systems and to improve the patient's health condition, the patient's spiritual care should not be ignored. This study aimed to identify spiritual care practice among ICU Nurses at public hospitals in rural areas. This survey study used the NSCTS (Nursing Spiritual Therapeutics Scale) questionnaires to identify spiritual care in the ICU wards. This study involved 39 ICU nurses who work in the three public hospitals of Pekalongan Regency, Central Java Indonesia (Kajen Hospital, Kraton Hospital, and Bendan Hospital). Data were analyzed by using Microsoft excel. The result of this study revealed that the average spiritual care among ICU nurses is 3.79. In the context of the spiritual care item question, the highest mean score was "Offered to pray with a patient," whereas the lowest was "Documented spiritual care you provided in a patient chart." Despite the study limitation, this study encourages the ICU nurses to record the spiritual nursing care into nursing care sheets.
\end{abstract}

This work is licensed under a Creative Commons Attribution 4.0 International License.

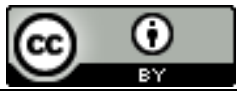

Corresponding Author:

Benny Arief Sulistyanto,

Faculty of Health Sciences, Universitas Muhammadiyah Pekajangan Pekalongan,

Ambokembang Rd. No. 8, Pekalongan, Central Java, Indonesia

Email: benny.arief@gmail.com

\section{INTRODUCTION}

Spiritual needs are one of the basic needs needed by patients to maintain or restore faith and fulfill religious obligations, and the need to get forgiveness or forgiveness, love, establish a trusting relationship with God. [1] Every healthy and sick individual needs spiritual care. [2]

Nurses have an obligation to provide health services comprehensively. All aspects encompassed biological, psychological, social, cultural, and spiritual should be delivered holistically and uniquely to health changes by nurses . [1]

The Indonesian Nursing Act (2014) article 30 point 1 states that nurses have the duty and authority to provide holistic health services. Similarly, ICN (2012) also states that the spiritual aspect of nursing care is a task that needs to be carried out by all nurses to the patients. Several factors that may affect nurses' willingness to provide spiritual care to patients are divided into two categories which are intrinsic and extrinsic factors. The intrinsic factors include the inability of nurses to communicate, nurses' confidence, lack of spiritual knowledge, and fear of making mistakes when providing care. In comparison, the extrinsic factors include hospital organization and management, lack of nurses in health care units, lack of time, and lack of nurse training on spiritual care. 
The practice of fulfilling patients' spiritual needs can be demonstrated through empathy, compassion, listening to patient stories, communicating and interacting with patients, treating patients with respect, helping patients in finding meaning and purpose in life, supporting them with their culture and religious beliefs, restoring faith or their beliefs, and find hope for patients .[3]

When a patient is in a state of illness, loss, or grief, a person's energy will decrease to affect the patients' mental health. Hence, spiritual care must be integrated into nursing practice to meet patients' spiritual needs. [4]

Furthermore, patients with terminal or critical conditions need more spiritual care [5]. By providing spiritual care to the critical patient, the patient can achieve peace of mind, stability in undergoing his illness, tranquility, decreased anxiety, and provides strength and comfort [6].

Patients and their families in the ICU must face all the changes due to their illness and a series of treatments to support life in critical condition [7]. Therefore, nurses may focus on various life-saving treatments, including intensive monitoring and therapy, life support equipment such as ventilators, patient monitors, or other invasive devices to improve body functions. Therefore, the spiritual aspect of patients and families is often neglected [6]. Ristianingsih, Septiwi, and Yuniar [8] stated that 41.7\% of ICU nurses provided spiritual care in the poor category. This showed that the implementation of spiritual care in the ICU had not been carried out optimally.

The condition of terminal patients, especially those treated in the ICU, has a high risk of experiencing life-threatening problems, fear, physical pain, isolation, the unexpected or uncertain situation [9]. If the patient's spiritual needs are not fulfilled, the patient will be vulnerable to experiencing spiritual distress [10]. Spiritual distress is characterized by patients always asking the truth of their beliefs, patients feeling uncomfortable about their beliefs and values, inability to carry out religious activities, as usual, doubting the values of their beliefs, expressing feelings of not wanting to live, expressing feelings of anger, anxiety, fear, suffering, saying do not want to relate to other people or God [10]. Yaseda, Noorlayla, and Efendy [11] also stated that insufficient fulfillment of spiritual needs would exacerbate their disease, especially in patients with terminal illnesses. This is because most patients would feel frustrated and give up on their condition so that external therapy such as drugs medicine cannot cure; therefore, beliefs and beliefs significantly affect the management of the disease. This study aimed to explore how ICU nurses in rural hospitals provide spiritual care therapeutics.

\section{RESEARCH METHOD}

The instrument in this survey study was The Nurse Spiritual Care Therapeutics Scale (NSCTS) measures the frequency of 17 therapeutics determined by an expert panel to represent spiritual care appropriate for a nurse to provide [12]. The questionnaire to fulfill the patient's spiritual needs was measured using the NSCTS (Nursing Spiritual Care Therapeutics Scale) questionnaire. This questionnaire is specific to assess/measure the frequency of nurse activities in meeting the spiritual needs of patients, as well as nursing actions taken by nurses to meet patient needs during the last three days in caring for patients in hospitals with the criteria of working 8 hours a day each [13]. This questionnaire consists of 17 question items using a Likert scale. In the criteria for answering the questionnaire, it can be determined from the frequency of the nurse's actions in providing spiritual care carried out by nurses with the choice of Never ( 0 times or never done at all $)=1$, Rarely $($ done 1-2 times $)=2$, Sometimes $($ done 3-6 times $)=3$, Often $($ done 7-11 times $)=4$, Very often (done more than 12 times $)=5$.

Since the NSCTS (Nursing Spiritual Therapeutics Scale) in Bahasa Indonesia was unavailable, the English version of NSCTS questionnaires was translated into Bahasa Indonesian using a backward-forward method. Two translators translated the original questionnaire into Bahasa Indonesia. Then the Bahasa Indonesia version questionnaire was compared to the original version by two experts. In addition, six experts were asked to validate the contents of the questionnaire Bahasa Indonesia version. Content validity Index showed that S-CVI) was 0.97 , and for the I-CVI, all question items $>0.80$.

This study involved all nurses in the ICU who work in hospitals in the area of Pekalongan regency as many as 39 nurses. All ICU nurses participated in this study, encompassed 11 respondents at Kajen Hospital, 14 respondents at Kraton Hospital, and 14 respondents at Bendan Hospital. The research was conducted in June 2019. The inclusion criteria in this study were Nurses in the ICU at Kraton Hospital, Kajen Hospital, and Bendan Hospital who are willing to be respondents. The exclusion criteria in this study are Nurses who are on leave during the research process and nurses who resigned as research respondents. Data were managed and analyzed using Microsoft excel. 


\section{RESULT AND DISCUSSIONS}

\subsection{Result}

The average age of the respondents in this study was 37, with a standard deviation of 4.898 . The youngest respondent in this study was 29 years old, and the most senior was 48 years old. $53.8 \%$ of respondents were male, and most were vocational nursing $(76.9 \%)$. All respondents $(100 \%)$ respondents are Muslim and Javanese. Most of the respondents are active in religious activities, as many as 37 (94.9\%). Most respondents have never attended seminars or workshops or training related to spiritual care, as many as 24 (94.9\%). All respondents (100\%) had working experience in ICU for more than five years. The details of characteristics and the nurse spiritual care therapeutic scale are in table below.

Table 1. Socio-demographic and clinical characteristics of the sample $(\mathrm{n}=39)$

\begin{tabular}{|c|c|c|c|c|c|}
\hline Characteristics & $\mathbf{n}$ & $\%$ & Mean & Min & Max \\
\hline Age & & & 37.18 & 29 & 48 \\
\hline \multicolumn{6}{|l|}{ Gender } \\
\hline Male & 21 & 53.8 & & & \\
\hline Female & 18 & 46.2 & & & \\
\hline \multicolumn{6}{|l|}{ Education Level } \\
\hline Vocational Nurses (three years) & 30 & 76.9 & & & \\
\hline $\begin{array}{l}\text { Bachelor of Science in Nursing } \\
\text { (four years) }\end{array}$ & 3 & 7.7 & & & \\
\hline $\begin{array}{l}\text { Nursing Profesional (BSN + one } \\
\text { year) }\end{array}$ & 6 & 15.4 & & & \\
\hline \multicolumn{6}{|l|}{ Religion } \\
\hline Islam & 39 & 100 & & & \\
\hline \multicolumn{6}{|l|}{ Religious Activity } \\
\hline Active & 37 & 94.9 & & & \\
\hline Not active & 2 & 5.1 & & & \\
\hline \multicolumn{6}{|l|}{ Tribe } \\
\hline Java & 39 & 100 & & & \\
\hline \multicolumn{6}{|l|}{ Spiritual care seminar attendance } \\
\hline Ever & 15 & 38.5 & & & \\
\hline Never & 24 & 61.5 & & & \\
\hline \multicolumn{6}{|l|}{ Working Experience } \\
\hline$>5$ years & 39 & 100 & & & \\
\hline
\end{tabular}


Table 2. The nurse spiritual care therapeutic scale questions

\begin{tabular}{|c|c|c|c|c|c|c|c|}
\hline \multirow[t]{2}{*}{ No. } & \multirow[t]{2}{*}{ Questions } & \multirow{2}{*}{$\begin{array}{l}\text { Mean } \\
\text { Score }\end{array}$} & \multicolumn{5}{|c|}{ NCTS Likert Scale (\%) } \\
\hline & & & Never & Rarely & Sometimes & Often & Very often \\
\hline 1 & $\begin{array}{l}\text { Asked a patient about how you could } \\
\text { support his or her spiritual or religious } \\
\text { practices }\end{array}$ & 3.23 & 2.6 & 17.9 & 38.5 & 35.9 & 5.1 \\
\hline 2 & $\begin{array}{l}\text { Helped a patient have quiet time or } \\
\text { space }\end{array}$ & 4.18 & & 2.6 & 12.8 & 48.7 & 35.9 \\
\hline 3 & $\begin{array}{l}\text { Listened actively to patient's story of } \\
\text { illness }\end{array}$ & 4.13 & & & 17.9 & 51.3 & 30.8 \\
\hline 4 & $\begin{array}{l}\text { Assessed a patient's spiritual or } \\
\text { religious beliefs and/or practices that } \\
\text { are pertinent to health }\end{array}$ & 4.23 & & & 17.9 & 41.0 & 41.0 \\
\hline 5 & $\begin{array}{l}\text { Listened to patient talk about spiritual } \\
\text { concerns }\end{array}$ & 4.15 & & 2.6 & 17.9 & 41.0 & 38.5 \\
\hline 6 & $\begin{array}{l}\text { Encouraged patient to talk about how } \\
\text { illness affects relating to God-or his } \\
\text { or her transcendent reality }\end{array}$ & 3.74 & & 7.7 & 25.6 & 51.3 & 15.4 \\
\hline 7 & $\begin{array}{l}\text { Encouraged patient to talk about his } \\
\text { or her spiritual coping }\end{array}$ & 3.33 & & 5.1 & 59.0 & 33.3 & 2.6 \\
\hline 8 & $\begin{array}{l}\text { Documented spiritual care you } \\
\text { provided in a patient chart }\end{array}$ & 3.15 & 5.1 & 20.5 & 35.9 & 30.8 & 7.7 \\
\hline 9 & $\begin{array}{l}\text { Discussed a patient's spiritual care } \\
\text { needs with colleagues (e.g., shift } \\
\text { report) }\end{array}$ & 3.90 & & 7.7 & 28.2 & 30.8 & 33.3 \\
\hline 10 & $\begin{array}{l}\text { Arranged for a chaplain to visit a } \\
\text { patient }\end{array}$ & 3.97 & & 7.7 & 17.9 & 43.6 & 30.8 \\
\hline 11 & $\begin{array}{l}\text { Arranged for patient's clergy/spiritual } \\
\text { mentor to visit }\end{array}$ & 3.90 & 2.6 & 10.3 & 17.9 & 33.3 & 35.9 \\
\hline 12 & $\begin{array}{l}\text { Encouraged a patient to talk about } \\
\text { what gives his or her life meaning } \\
\text { amid illness }\end{array}$ & 3.59 & 2.6 & 10.3 & 30.8 & 38.5 & 17.9 \\
\hline 13 & $\begin{array}{l}\text { Encouraged a patient to talk about the } \\
\text { spiritual challenges of living with } \\
\text { illness }\end{array}$ & 3.56 & & 10.3 & 35.9 & 41.0 & 12.8 \\
\hline 14 & Offered to pray with a patient & 4.41 & & & 12.8 & 33.3 & 53.8 \\
\hline 15 & $\begin{array}{l}\text { Offered to read a spiritually nurturing } \\
\text { passage (e.g., patient's holy scripture) }\end{array}$ & 3.85 & & 7.7 & 30.8 & 30.8 & 30.8 \\
\hline 16 & $\begin{array}{l}\text { Told a patient about spiritual } \\
\text { resources }\end{array}$ & 3.33 & & 23.1 & 30.8 & 35.9 & 10.3 \\
\hline \multirow[t]{2}{*}{17} & $\begin{array}{l}\text { After completing a task, remained } \\
\text { present just to show caring }\end{array}$ & 3.82 & & 7.7 & 23.1 & 48.7 & 20.5 \\
\hline & Total Average & 3.79 & & & & & \\
\hline
\end{tabular}

\subsection{Discussion}

This study revealed that ICU nurses were inadequate in providing spiritual care to ICU patients (3.79 overall means score from 1 to 5 scale). However, ICU nurses had a good score in the aspect of "Offered to pray with a patient," with the mean score is 4.41 . The primary focus of the nursing intervention at ICU patients was to allow the ill person the opportunity to receive whatever spiritual support or comfort they needed as death approached. "Nursing, as a profession, will embrace more than an art and a science; it will be a blending of three factors: of art and science, and the spirit of unselfish devotion to a cause primarily concerned with helping those who are physically, mentally or spiritually ill". In contrast, in spiritual care documentation, ICU nurses may neglect to record spiritual care nursing care. Nurses must be diligent in charting the process of the spiritual care they provide so that the data can be used to demonstrate the improvement in patient health. Documentation can serve to justify the amount of nursing time spent providing spiritual care and perhaps influence the reimbursement system, thereby increasing staffing. 
Documentation may seem like a task that is not central to providing spiritual care, but it is. Imagine how powerful it would be if nurses could report that length of stay was reduced by one day and that patient satisfaction increased for the patient receiving quality spiritual care.

The ICU patients may experience a state of critical conditions. This may require various therapies such as ventilators and drugs. As a result, patients' five senses may be impaired and cause them to have difficulty expressing or verbally communicating their needs. However, this does not mean that patients in the ICU do not have spiritual needs. Instead, giving spiritual care to patients will be a source of strengthening their beliefs [6]. The practice of fulfilling the spiritual needs of patients in the ICU is part of a holistic nurse's task, but spiritual needs are often neglected in practice. Nurses do not fully meet the spiritual needs of patients because nurses focus more on fulfilling the patient's biological needs [14].

A nurse is someone who interacts with patients for 24 hours. Therefore, nurses have a vital role in helping meet the spiritual needs of patients by providing spiritual care to patients, either by bringing religious leaders with at the patient's beliefs, giving patients a place to pray, and giving time to the patient. Patients may be able to interact with other people, family, and friends [1]. Spiritual care is essential to overcome emotional changes during a crisis [14]. Assessing whether the patient's spirituality is disturbed due to hospital treatment is critical. If the patient experiences spiritual distress and health problems, the patient will despair, which leads to a decline in the patient's health [15].

Ristianingsih, et al. [8] found a similar result that less than $50 \%$ of nurses were inadequate in providing spiritual care to the patient. Therefore, an educational program related to spiritual care is necessary. Rachmawati, et al. [16] added that the practice of spiritual care among nurses was still lacking. Nurses not asking whether patients and families need religious leaders, not encouraging family or relatives to pray or remind worship. Utami [17] also stated that nurses paid less attention to aspects of spiritual care in care because they did not understand the spiritual aspects and their benefits to the healing process of patients' illnesses and patient's health. Therefore, the practice in providing spiritual care should be improved to achieve high quality of nursing care.

The critical care environment is filled with monitors, alarms, ventilators, cardiac monitors, and other life support machines; this environment is a challenge in providing spiritual care. Nurses are expected to integrate spiritual care as a daily routine to help ICU patients to cope with their problems. In this study, spiritual care was provided in the ICU nurses by "giving mental support, facilitating religious rituals, communicating with patients and patient's families, assessing patients' spiritual needs, and showing respect. Nurses should investigate potential religious needs to promote spiritual health.

Nurses were unable to fulfill patients' spiritual needs for some reason. The main barriers to spiritual care are the difficulty in defining spirituality, the lack of clear guidelines for the nurse's role in providing spiritual care; nurses' lack of time to provide spiritual care; and a lack of training and education on spirituality for pre and post-registration nurses. Many nurses use the excuse that they don't have time to provide spiritual care. Even in less pressured settings than a busy hospital, we tend to think that we are too busy to spend extended time exploring patient's spiritual needs.

The nurse should be able to identify the patient's spiritual needs to prevent spiritual distress. This study showed that moslem ICU nurses were concerned in listening to ICU patients regarding their spiritual problems (as questions no. 2-6 were high average scores). Spiritual or religious practice may be changed in ICU patients as most critical care patients are sedated, intubated, and connected to life support machines. The patients may not be able to perform religious activities during this phase. This study revealed that moslem nurses very often to offer to pray with the patient (question no. 14). This may reflect that the religious aspect may be considered important things by ICU nurses in this study. Nurses can collaborate with patient's families can help the patient in providing religious activity such as reciting Qur'an in front of the patient.

\section{CONCLUSION}

This study revealed the evidence for the need to improve spiritual care education and support for nurses, especially those who work in ICU. These findings indicate that ICU nurses had to improve their spiritual care documentation. This study is a first step toward understanding how ICU nurses in the rural Hospital perceived their spiritual care interventions. Additional research is needed to measure spiritual care from patients' or family perspectives.

\section{Acknowledgements}

Thank you to Universitas Muhammadiyah Pekajangan Pekalongan for funding Support. 


\section{REFERENCES}

[1] A. Y. S. Hamid, "Asuhan Keperawatan Kesehatan Jiwa Bunga Rampai," 2008: EGC.

[2] A. Yusuf, H. E. Nihayati, M. F. Iswari, and F. J. B. R. Okviansanti, "Kebutuhan spiritual: konsep dan aplikasi dalam asuhan keperawatan," ed: Mitra Wacana Media, 2016, pp. 1-316.

[3] L.-F. Wu, H.-C. Tseng, and Y.-C. J. N. e. t. Liao, "Nurse education and willingness to provide spiritual care," vol. 38, pp. 36-41, 2016.

[4] S. Willemse, W. Smeets, E. van Leeuwen, T. Nielen-Rosier, L. Janssen, and N. J. J. o. c. c. Foudraine, "Spiritual care in the intensive care unit: An integrative literature research," vol. 57, pp. $55-78,2020$.

[5] H. Hasrul, "Hubungan Tingkat Pengetahuan Perawat Terhadap Pelaksanaan Asuhan Keperawatan Spiritual Di Ruang Perawatan Rumah Sakit Nene Mallomo Kabupaten Sidenreng Rappang," Jurnal Keperawatan Muhammadiyah, vol. 2, p. 1, 2017.

[6] W. Wardah, R. Febtrina, and E. J. J. E. K. I. P. K. Dewi, "Pengaruh Pengetahuan Perawat Terhadap Pemenuhan Perawatan Spiritual Pasien Di Ruang Intensif," vol. 2, no. 3, pp. 436-443, 2017.

[7] A. N. Aflah, "Hubungan spiritualitas dengan tingkat kecemasan keluarga pasien di ruang ICU (intensive care unit) RSUD dr. Loekmono Hadi Kudus," Prosiding HEFA, vol. 1, no. 1, 2017.

[8] D. Ristianingsih, C. Septiwi, and I. J. J. I. K. K. Yuniar, "Gambaran motivasi dan tindakan keperawatan dalam pemenuhan kebutuhan spiritual pasien di ruang ICU PKU Muhammadiyah Gombong," vol. 10, no. 2, 2014.

[9] D. Permatasari and A. Pujianto, "Hubungan Tingkat Spiritualitas dengan Motivasi Sembuh pada Pasien Kritis di RSUD dr. Moewardi Surakarta," Universitas Diponegoro, 2017.

[10] B. A. Keliat, A. P. Wiyono, and H. J. J. E. Susanti, "Manajemen kasus gangguan jiwa: CMHN (intermediate course)," 2011.

[11] G. Y. Yaseda, S. F. Noorlayla, and M. A. a. J. S. J. I. K. Efendy, "Hubungan Peran Perawat Dalam Pemberian Terapi Spiritual Terhadap Perilaku Pasien Dalam Pemenuhan Kebutuhan Spiritual Di Ruang ICU RSM Ahmad Dahlan Kota Kediri," vol. 2, no. 2, pp. 41-49, 2013.

[12] E. J. Taylor, I. Mamier, P. Ricci-Allegra, and J. Foith, "Self-reported frequency of nurse-provided spiritual care," Applied Nursing Research, vol. 35, pp. 30-35, 2017/06/01/ 2017.

[13] I. Mamier and E. J. J. W. J. o. N. R. Taylor, "Psychometric evaluation of the nurse spiritual care therapeutics scale," vol. 37, no. 5, pp. 679-694, 2015.

[14] Nurherawati, E. Rachmawati, and M. Bigwanto, "The Relationship of Characteristics and Intelligence of Nursing Spirituals with Fulfilling the Needs of Inpatient Spiritual Services," ARKESMAS, vol. 4, no. 2, p. 179, 2019.

[15] J. Crisp, C. Taylor, C. Douglas, and G. Rebeiro, Potter \& Perry's Fundamentals of Nursing-AUS Version-E-Book. Elsevier Health Sciences, 2012.

[16] N. Rachmawati, L. Dwiantoro, and B. E. J. J. N. D. K. I. Warsito, "Pengaruh Metode Drill dalam Supervisi Klinis terhadap Spiritual Care Perawat," vol. 5, no. 2, pp. 115-122, 2017.

[17] Y. W. Utami, "Hubungan Antara Pengetahuan Dengan Sikap Perawat Dalam Pemenuhan Kebutuhan Spiritual Pasien Di BRSUD Sukoharjo," 2009. 